НАУКОВИЙ ВІСНИК

Scientific messenger of Lviv National University

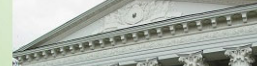

TIIIII

2.

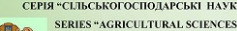

Том 22 № 93 2020
Науковий вісник Дьвівського національного університету ветеринарної медицини та біотехнодогій імені С.3. Гжицького. Серія: Сільськогосподарські науки

Scientific Messenger of Lviv National University of Veterinary Medicine and Biotechnologies. Series: Agricultural sciences https://nvlvet.com.ua/index.php/agriculture

UDC 636.52

\title{
Prospects for the use of peat in biotechnology and for production products of its processing
}

O. O. Korytko

Stepan Gzhytskyi National University of Veterinary Medicine and Biotechnologies Lviv, Lviv, Ukraine

Article info

Received 09.09.2020

Received in revised form 09.10 .2020

Accepted 12.10.2020

Stepan Gzhytskyi National University of Veterinary Medicine and Biotechnologies Lviv, Pekarska Str., 50, Lviv, 79010, Ukraine.

Tel.: +38-096-632-65-12

E-mail:biochem@lvet.edu.ua
Korytko, 0.0. (2020). Prospects for the use of peat in biotechnology and for production products of its processing. Scientific Messenger of Lviv National University of Veterinary Medicine and Biotechnologies. Series: Agricultural sciences, 22(93), 126-131. doi: 10.32718/nvlvet-a9321

The article summarizes information on the use of peat - a natural substrate in agro-industrial production, maintaining the cleanliness of the soil and maintaining the cleanliness of the environment. Intensive anthropological activity in modern conditions often leads to the deterioration of the ecological situation of the environment, disruption of the interaction between living organisms and the environment. Biological destruction of the ecological system inherent in a given area can occur under the influence of excessive use of agrochemicals, pesticides, microorganisms with altered characteristics due to interaction with infectious agents or parasites, as well as due to changes in the gene pool of living under the influence of genetic engineering. At the present stage in world development, importance is attached to the approximation of agricultural technologies to the natural conditions of operation. Cleaning the environment, preserving and increasing soil fertility, obtaining high-quality and environmentally friendly agricultural products is a vital but at the same time costly process, which involves significant economic costs. Therefore, there is a need to find cheap ways to solve this problem, replace expensive fertilizers with alternative means, the rational use of biological factors that increase the effectiveness of chemicals. For this purpose, biosubstrates, peat, natural fertilizers and preparations are widely used in world, especially organic agriculture, which are created by the method of selection of effective compositions of microorganism strains in order to activate regenerative processes in soils and ensure their potential. Peat is a natural raw material, an important agro-industrial resource with great potential, which has a multifaceted application. The most reactive part of peat is the population of microorganisms. With the participation of symbiotic microorganisms, the mineralization of peat components occurs, as a result of which nutrients become available to plants. The practice of using peat in agriculture shows its effectiveness as an organic fertilizer, peat-based composts increase soil fertility, agricultural productivity in general, improve environmental cleanliness. Peat has long been used in livestock facilities for bedding. Peat litter has advantages over straw litter due to its high absorption and moisture retention capacity, antibiotic properties. Waste litter is used for composting, as a valuable organic fertilizer to improve soil fertility. Peat is an important source of humic substances in the world, so it is used to produce humic preparations.

Key words: peat, biotechnology, ecology, agriculture.

\section{Перспективи застосування торфу у біотехнології та для одержання продуктів його переробки}

О. О. Коритко

Львівський національний університет ветеринарної медицини та біотехнологій імені С. 3. Гжицького, м. Львів, Україна

У статті у стислій формі наведені відомості про застосування торфу - природного субстрату у агропромисловому виробництвві, підтриманні чистоти трунтового покриву та збереженні чистоти довкілля. Інтенсивна антропологічна діяльність в сучасних умовах часто веде до погіршення екологічної ситуації довкілля, порушення взаємодії між живими організмами та навколишнім 
середовищем. Біологічне руйнування екологічної системи, притаманної даній місиевості, може відбуватись під впливом надмірного використання агрохімікатів, пестицидів, мікроорганізмів зі зміненими особливостями внаслідок взаємодії із збудниками інфекцій чи паразитами, а також внаслідок зміни генофонду живого під впливом генної інженеріі. На сучасному етапі у світовому розвитку важливе значення надається наближенню агротехнічних технологій до природних умов функціонування. Очищення навколишнього середовища, збереження та підвищення родючості трунтів, одержання якісної і екологічно чистої продукиії сільського господарства - життєво важливий, але одночасно і коштовний процес, який пов'язаний зі значними економічними затратами. Тому виникає необхідність пошуку дешевих способів вирішення иього питання, заміни дорогих мінеральних добрив альтернативними засобами, раціонального використання біологічних факторів, які підвищують ефективність засобів хімізації. 3 цією метою широке використання у світовому, особливо органічному землеробстві, мають біосубстрати, торфи, природні добрива та препарати, які створені на методом підбору ефективних композицій штамів мікроорганізмів з метою активації відновлювальних процесів у грунтах та забезпечення їх потенціалу. Торф - природна сировина, важливий агропромисловий ресурс з великим потенціалом, який має багатопланове застосування. Найбільш реактивною частиною торфу є популяція мікроорганізмів. За участю симбіотичних мікроорганізмів відбувається мінералізачія компонентів торфу, внаслідок чого поживні речовини стають доступними для рослин. Практика застосування торфу у сільському господарстві показує його ефективність як органічного добрива, компости на основі торфу підвищують родючість трунтів, продуктивність сільського господарства в иілому, покрашують екологічну чистоту довкілля. Торф здавна використовують у тваринницьких примішеннях для підстилки. Торф'яна підстилка має переваги над підстилкою зі соломи завдяки високій поглинальній і вологоутримуючій здатності, антибіотичним властивостям. Відпраиьовану підстилку використовують для виготовлення компостів, як иінне органічне добриво для покращення родючості трунтів. Торф є важливим джерелом гумінових речовин у світі, тому його використовують для одержання гумінових препаратів.

Ключові слова: торф, біотехнологія, екологія, сільське господарство.

\section{Вступ}

Інтенсивний розвиток цивілізації часто погіршує екологічну ситуацію, веде до порушення рівноваги між живими організмами та навколишнім середовищем. Через негативний вплив хімічних речовин, важких металів, пестицидів, популяцій мікроорганізмів зі зміненими особливостями, які виникають внаслідок взаємодії із збудниками інфекцій чи паразитами, може відбуватись біологічне руйнування екологічної системи, притаманної даній місцевості. Біотехнологія, генна інженерія також можуть наносити непоправну шкоду природі через вплив на генофонд живого.

Під постійним антропогенним впливом перебувають грунтові покриви, в результаті чого наступає погіршення їх екологічного стану. Проблемою в системі інтенсифікації сільського господарства $є$ деградація родючості грунтів (Situmorang et al., 2015). Хімізація сільськогосподарських угідь, меліоративні заходи, інтенсифікація агропромислового виробництва спричиняють забруднення та виснаження грунтів (Pronevych, 2014).

Основним завданням в умовах загострення екологічної ситуації є очищення довкілля, підтримки родючості грунтів, забезпечення населення якісними продуктами харчування. На сучасному етапі світового розвитку великого значення набуває наближення індустріальних технологій аграрного сектору до природних умов (Pervachuk \& Vradii, 2015).

В умовах екологічного забруднення порушується структура мікробних популяцій грунтового покриву, зростає чисельність небезпечних для людей грибів, зменшується чисельність грунтових бактерій. Грунтові мікроорганізми відіграють основну роль у розкладанні органічних рослинних i тваринних решток, здійснюють мінералізацію і беруть участь в утворенні гумусу. В умовах інтенсифікації виробництва відбувається поступова деградація грунтового покриву урбанізованих територій, хімічне і біологічне забруднення веде до зменшення родючості грунтів (Medvedeva et al., 2018).

Урбанізація та індустріалізація безпосередньо впливають на родючість грунтів, продуктивність сіль- ськогосподарського виробництва, продовольчу безпеку. Стале виробництво продуктів харчування вимагає забезпечення якісних високих урожаїв, екологічної чистоти та економічної рентабельності сільського господарства (Pervachuk \& Vradii, 2015). Очищення навколишнього середовища - життєво важливий, проте економічно коштовний процес. Тому актуальним $є$ пошук дешевих способів і засобів для вирішення проблеми екологічної безпеки. 3 цією метою використовують біосубстрати, природні добрива, які містять гумінові речовини, а також препарати, створені методом підбору високоефективних композицій штамів мікроорганізмів, що здійснюють деструкцію шкідливих сполук (Heisun \& Stepchenko, 2017).

На особливу увагу заслуговує розробка технологій переробки місцевої сировини на органічні й органомінеральні добрива, застосування біостимуляторів, які збагачують грунти поживними речовинами, відновлюють гумус, покращують його якість.

Розроблено безпечні технології біоочищення середовища, забрудненого пестицидами, за допомогою біосорбційних комплексів із мікроорганізмамидеструкторами, закріпленими на сорбційно-активних носіях щодо забруднювачів (Khokhlov et al., 2019). Внесення мікроорганізмів-деструкторів шляхом обприскування грунту мікробною суспензією поліпшує його біологічні властивості, підвищує функціональну активність мікробної популяції (Zharikov et al., 2018).

\section{Результати та їх обговорення}

Різними дослідженнями встановлено позитивний вплив біодобрив на фізичні, хімічні та біологічні властивості грунту. Застосування біодобрив дозволяє заощадити витрати на дорогі сировинні ресурси, які в даний час споживаються з невідновлюваних джерел енергії. Тому важливою $є$ розробка дешевих та екологічно чистих добрив (Chuang et al., 2007; Neneng, 2020).

Широке використання у світовому, особливо органічному землеробстві, має торф. 80 \% світового видобутку торфу використовують у сільському господарстві для підвищення родючості грунтів (Kravchuk et al., 
2018). Великі торф’яні ресурси країни мають унікальний природний потенціал і за своїм складом придатні до використання в енергетичному, промисловому, агропромисловому виробництві. 3 розвитком науки торф став перспективним джерелом біотехнології, охорони довкілля та здоров'я людей.

Торф видобувають на торфовищах. Це дешевий, легкодоступний протягом цілого року сировинний матеріал, джерело органічних речовин. Завдяки цьому його можна застосовувати як органічне добриво для поліпшення характеристик бідних на гумус піщаних, глинистих грунтів, на газонах, в садах, у городах, в органічному землеробстві. Торф покращує фізичні властивості мінеральних грунтів, підвищує їхню врожайність.

Великі торф'яні масиви несуть у собі великий потенціал для сільського господарства та рослинництва (Situmorang et al., 2015).

Торфове виробництво проявляє локальний ефект на навколишнє середовище. Вода, яка стікає при торфодобуванні, не утримує отрутохімікатів або небезпечних бактерій. Золу, утворену при спалюванні торфу, можна застосовувати як добриво для поліпшення складу і структури грунтів. Використання торфу для утилізації відходів птахокомбінатів та тваринницьких ферм дає можливість отримати ефективні екобезпечні торфопослідні, торфогнійні добрива, які є стимуляторами якості і продуктивності сільськогосподарського виробництва (Bondar et al., 2012).

В Україні виробляють органічні добрива з використанням гною, курячого посліду, тирси, соломи, компостів та продукти на основі торфу. У сільському господарстві торф використовують для виготовлення компостів, підстилки для тварин, органічного добрива для відновлення родючості грунтів та поліпшення екологічної чистоти довкілля (Veremeienko et al., 2017). Напрямки застосування торфу для виготовлення мінерально-органічних добрив, компостів у землеробстві розширюються (Kravchuk et al., 2018).

Висока гігроскопічність торфу, здатність поглинати і затримувати тривалий час воду дозволяє використовувати його для поглинання неприємних запахів, усунення шкідливих субстанцій 3 води і стоків, для очищення середовища, а також як підстилку у тваринництві.

Застосування торфу при знезараженні стічних вод і осаду, який залишається після їхнього очищення, може бути перспективним способом очищення довкілля. Цьому сприяє висока сорбційна здатність, зокрема щодо важких металів, розчинених у водах, які можуть становити загрозу для живих організмів, якщо їхня концентрація перевищує допустимі норми.

Важливим етапом у різних галузях сільського господарства, зокрема у птахівництві, є вибір субстрату для підстилки. Дослідженнями окремих авторів встановлено, що підстилка має важливе значення (Mendes et al., 2011). У сучасному птахівництві курей утримують на глибокій підстилці. Для підстилки використовують тирсу, солому, торф, подрібнені качани кукурудзи. Торф'яна підстилка за властивостями переважає солом'яну. Важливою перевагою торф'яної підстилки є те, що вона усуває неприємний запах, захищає кінцівки птиці від переохолодження. Торф'яну підстилку рекомендують застосовувати в умовах сучасного ведення сільського господарства (Kravchuk et al., 2018).

Використання глибокої торф'яної підстилки сприяє поліпшенню мікроклімату у тваринницькому приміщенні, фізіологічного стану тварин і птиці, зростанню продуктивності. Торф'яна підстилка має антисептичні властивості завдяки антибіотичним речовинам i кислій реакції, впливає на якісний і кількісний склад мікрофлори тваринницького приміщення, відвертає розвиток хвороботворних мікроорганізмів. За результатами досліджень деяких авторів (Kaukonen et al., 2017), при використанні торф'яної підстилки для бройлерів виявлено зменшення контактного дерматиту порівняно з тирсою та меленою соломою.

Висока поглинальна здатність торф'яної підстилки дає можливість зв'язувати гази, такі як аміак, сірководень, поглинати сечу, гноївку, утримувати тепло. Таку підстилку можна використати як добриво, що постачає грунт органічними сполуками, мікро- і мікроелементами.

У Фінляндії торф є стандартним, легкодоступним (за прийнятною ціною) матеріалом для підстилки при вирощуванні бройлерів, а відпрацьована торф'яна підстилка застосовується як цінне добриво на полях (Cocozza et al., 2003).

Проведені нами попередні дослідження з використання торф'яної підстилки на птахофабриці Жовтнева Жовківського району Львівської області показали позитивний вплив на яйценосність курей-несучок та епідеміологічну ситуацію пташника.

Використання підстилки, підстилкового гною збагачує грунт азотом, поживними речовинами, знижує його кислотність на $25 \%$ порівняно із застосуванням міндобрив. Підстилка $є$ потужним чинником родючості грунтів (Pervachuk \& Vradii, 2015).

Торф має властивості натурального сорбенту. Торф відіграє важливу роль у зв'язуванні катіонів. Сорбційна здатність тим вища, чим вищий ступінь гуміфікації органічної маси. У сорбційній здатності торфу основну роль відіграють гумінові речовини.

Торф - це органогенна осадова порода, багатокомпонентна система 3 генетичними ознаками рослинного матеріалу, який тривалий час в умовах перезволоження піддавався мікробному розкладу в результаті біохімічних і структуральних процесів. Містить рослинні рештки з різним ступенем розкладу. Залежно від умов торфоутворення, водного живлення, рослинного складу, ступеня гуміфікації органічної частини склад і властивості різних торфів відрізняються між собою. Із вітчизняних геологічних запасів торфи низинного типу становлять $96 \%$, верхового типу $2,5 \%$. Перевагою низинних торфів є високий вміст гумінових речовин. Торф містить різні хімічні речовини, які визначають його біологічну активність та активність продуктів переробки. Торф - важливе джерело добування гумінових речовин у світі (Ozerchuk \& Hnieushev, 2015).

Цінні фізико-хімічні властивості дозволяють застосовувати торф у народному господарстві як сировину для одержання різних хімічних продуктів (біту- 
мів, кормових дріжджів, активованого вугілля, дьогтю), а завдяки бактеріологічним властивостям - для виготовлення медичних та ветеринарних препаратів для лікування захворювань різної етіології, підвищення запліднюваності тварин, стимулювання механізмів резистентності (Lotosh, 1991; Herashchuk, 1998; Yurchenko \& Vereshchun, 2005; Hryban et al., 2008).

Органічна частина торфу неоднорідна і представлена сумішшю речовин рослинного та, в основному, мікробного походження. Мікробна популяція $є$ найбільш реактивною частиною торфу як природного біоценозу, що розкладає і трансформує рослинні рештки і здійснює біосинтез біологічно активних сполук. Мікроорганізми торфу належать до різних таксономічних і фізіологічних груп, куди входять бактерії, актиноміцети та інші нижчі гриби (Lotosh, 1991; Nookongbut et al., 2019). У процесі життєдіяльності вони здійснюють біоконверсію метаболітів у структурно споріднені сполуки. До складу органічної частини торфу входять різні органічні сполуки, вміст яких залежить від активності процесів гуміфікації (Pronevych, 2014). Це динамічна система, яка постійно поновлюється в результаті утворення, трансформації та розпаду іiі компонентів. При цьому відбувається зв'язування мінеральних сполук, які стають доступними до засвоєння. У торфі також у незміненому вигляді зберігаються залишки вихідних рослинторфоутворювачів (Lotosh, 1991).

Існує складний механізм взаємодії між органічною i неорганічною частинами торфу, про що свідчать різні форми компонентів. Неорганічна частина представлена катіонами та аніонами хімічних елементів, неорганічними мінералами, органо-мінеральними комплексами, впливає на формування багатьох його фізико-хімічних та біологічних властивостей.

3 органічних речовин основна частка припадає на гумінові речовини - гумінові кислоти і фульвокислоти, які виконують різні функції, термодинамічно i біохімічно стійкі. Вміст гумінових речовин залежить від виду торфу: у верхових від 15 до $30 \%$, у низинних - 35-50 \%. Торф зі ступенем розкладу, вищим за $25 \%$, та вмістом гумінових кислот, більшим за $30 \%$, використовують як сировину для виробництва фізіологічно активних речовин і препаратів (Ozerchuk \& Hnieushev, 2015).

Гумінові кислоти - високомолекулярні ароматичні сполуки, які займають центральне місце серед органічних речовин торфу і мають важливий вплив на формування його властивостей. Ці сполуки є складовою частиною гумусових грунтів, утворюються в результаті розкладання біосировини в процесі гниття органічних решток рослинного і тваринного походження. Гумінові кислоти мають базове значення у функціонуванні системи “вода-грунт-рослина-твариналюдина" і на відміну від агрохімікатів, мінеральних добрив, пестицидів не виявляють побічної дії, безпечні для рослин, тварин і людей. Проявляють антибактеріальну та протизапальну дію. Їх використовують для одержання фармакологічних препаратів, косметичних засобів.

Гуміновим кислотам відводиться важливе значення у покращенні екологічної обстановки в аграрному секторі. Корисний ефект гумінових речовин як біостимуляторів росту рослин добре відомий ще з 1980-х років. Застосування гумінових речовин як біостимуляторів може бути важливою частиною сільського господарства. Попит на біостимулятори зростає щорічно в Свропі та Північній Америці. Важливим етапом $\epsilon$ включення гумінових речовин у метаболізмі рослин i їхньому захисті від патогенних мікроорганізмів (Jindo et al., 2020).

У сучасних умовах інтенсифікації агропромислового виробництва важливим напрямком є отримання гумінових композитів для виготовлення органомінеральних добрив (Tyshko et al., 2015).

Гумінові речовини входять до складу нових, екологічно безпечних гумінових добрив, створених на основі біотехнологічних методів. Ці добрива посилюють дію поживних речовин, поліпшують здатність утримувати воду, стимулюють життєдіяльність рослин і стійкість до впливу різних негативних чинників, підвищують врожайність, якість продукції та ії екологічну чистоту. При цьому зменшуються економічні затрати, підвищується рентабельність сільськогосподарського виробництва.

Завдяки здатності до йонного обміну і утворення комплексів гумінові кислоти застосовують як сорбенти для вилучення катіонів металів зі середовища, для очищення стічних вод (Khokhotva et al., 2016).

Гумінові препарати покращують родючість грунтів, проростання насіння, стимулюють ріст рослин, підвищують врожайність. Враховуючи світову тенденцію до створення і споживання органічних продуктів, гумінові препарати можуть мати добру перспективу на вітчизняному і зарубіжному ринку для підвищення ефективності роботи тих галузей господарства, які їх використовують (Ozerchuk \& Hnieushev, 2015; Bakai, 2017).

Перспективним напрямком є створення мікробіологічних препаратів, які включають різні бактерії та гриби, оздоровлюють грунт, вбивають патогенні мікроорганізми, мобілізують макро- і мікроелементи, роблять їх доступними для засвоєння. Біодеструктор стерні Екостерн - біопрепарат з високим вмістом гумінових кислот, містить бактерії та спори, які підвищують ступінь розкладу соломи, що залишається на полі та при перегниванні $є$ цінним альтернативним добривом (Bakai, 2017).

Даних щодо практичного застосування гумінових речовин у сільськогосподарських галузях, зокрема на полях, у зв'язку з впливом факторів (мінливість погоди, коливання клімату, тип грунту та спосіб управління полями) недостатньо (Cocozza et al., 2003; Rose et al., 2014; Canellas et al., 2015).

3 торфу вилучають гумати - солі гумінових кислот. Гумінові кислоти переводять у біологічно активний стан із широким спектром дії при розчиненні у лугах одновалентних металів. Водорозчинний гумат натрію отримано 3 торфу, в малих дозах стимулює ріст і розвиток рослин, підвищує поступлення поживних елементів, активує білковий і вуглеводний обмін, підвищує врожайність сільськогосподарських культур. 
Гумати i гідрогумати утворюють комплексні (хелатні) сполуки з металами, зокрема 3 мікроелементами. У складі хелатів мікроелементи краще засвоюються організмом тварин, компенсують дефіцит мікроелементів, сприяють впливу гумінових речовин на організм. Гумати застосовують у годівлі тварин і птиці як стимулятори росту, для посилення резистентності, підвищення приростів, яйценосності несучок, для прискорення росту і виживання риб. Не виявляють побічної дії на різні функції організму і практично нешкідливі (Hryban et al., 2008).

Полімінеральні кормові добавки гумат і торфогумат покращують клітинний обмін речовин, активують обмінні процеси, стимулюють розмноження інтестінальної і пригнічують ріст патогенної конкурентної мікрофлори, підвищують вміст загального білка крові (Yurchenko \& Vereshchun, 2005).

Багатим джерелом гумінових кислот та поживних речовин може бути компост, одержаний на основі торфу в процесі розкладу органічних решток, включно 3 відходами. У процесі компостування аеробні бактерії і гриби переводять недоступні для рослин сполуки у доступну для засвоєння форму.

Важлива проблема для землеробства - раціональне використання азоту може бути пов'язана із виготовленням біоорганічних добрив, компостів на основі торфу і їхнім застосуванням для покращення якості грунту, у ландшафтному дизайні, садівництві, міському господарстві та органічному землеробстві.

\section{Висновки}

В умовах загострення екологічної ситуації важливим $€$ очищення довкілля, забезпечення населення якісними продуктами харчування. Велике значення має наближення індустріальних технологій аграрного сектору до природних умов. Дешевою і ефективною сировиною із багатоплановим застосуванням може бути торф 3 місцевих родовищ. Торф містить комплекс мікро- і мікроелементів, різних органічних сполук, серед яких важливе місце належить гуміновим речовинам. Антисептичні властивості торф'яної підстилки дозволяють запобігти захворюванням тварин і птиці, поліпшити епідеміологічний стан тваринницьких приміщень,підвищити продуктивність тварин, яйценосність курей-несучок. Використання відпрацьованої торф'яної підстилки, органічних добрив i компостів на основі торфу є доцільним для підвищення родючості грунту. Торф треба широко застосовувати у практиці агропромислового виробництва, охороні довкілля.

\section{References}

Bakai, R. B. (2017). Poiednannia huminovykh preparativ ta solomy $\mathrm{v}$ yakosti orhanichnoho dobryva. Materialy Mizhnarodnoi naukovo-praktychnoi konferentsii "Dosiahnennia ta perspektyvy zastosuvannia huminovykh rechovyn u silskomu hospodarstvi". Dnipro, 24-25 (in Ukrainian).

Bondar, O. I., Konishchuk, V. V., Drebot, O. I., Havrylov, S. O., Konovalchuk, V. K., \& Blinkova, O. I. (2012).
Obgruntuvannia zbalansovanoho rozvytku torfovydobuvnoi haluzi z vrakhuvanniam pryrodookhoronnykh kryteriiv. Ekolohiia bolit i torfovyshch (Zbirnyk naukovykh stattei), 18-27. URL: http://www.agroeco.org.ua/images/Documents/Konisch uk/Zbirnuk_ecol_bolit_i_torfovisch\%202012.pdf (in Ukrainian).

Canellas, L. P., Olivares, F. L., Aguiar, N. O., Jones, D. L., Nebbioso, A., \& Mazzei, P. (2015). Humic and fulvic acids as biostimulants in horticulture. Sci. Hortic, 196, 15-27. doi: 10.1016/j.scienta.2015.09.013.

Chuang, C.-C., Yu-Lin Kuo, Chen-Ching Chao, \& WeiLiang Chao (2007). Solubilization of inorganic phosphates and plant growth promotion by Aspergillus niger. Biol Fertil Soils, 43, 575-584. doi: 10.1007/s00374-006-0140-3.

Cocozza, C., D'Orazioa, V., Miano, T. M., \& Shotyk, W. (2003). Characterization of solid and aqueous phases of a peat bog profile using molecular fluorescence spectroscopy, ESR and FT-IR, and comparison with physical properties. Organic Geochemistry, 34(1), 4960. doi: 10.1016/S0146-6380(02)00208-5.

Heisun, A. A., \& Stepchenko, L. M. (2017). Nakopychennia huminovykh rechovyn u biohumusi za vplyvu biolohichno aktyvnykh rechovyn. Materialy Mizhnarodnoi naukovo-praktychnoi konferentsii "Dosiahnennia ta perspektyvy zasto-suvannia huminovykh rechovyn u silskomu hospodarstvi”. Dnipro, 40-41 (in Ukrainian).

Herashchuk, M. I. (1998). Vuhlevodno-lipidnyi obmin u svynei riznoho viku za vplyvu preparativ humusovoi pryrody. Visnyk Dnipropetrovskoho derzhavnoho ahrarnoho universytetu, 5(2), 108-111 (in Ukrainian).

Hryban, V. H., Rakytianskyi, V. M., \& Yefimov, V. H. (2008). Fizioloho-biokhimichnyi status holshtynskoi khudoby za vplyvu hidrohumatu $\mathrm{z}$ poiednanniam mikroelementiv. Visnyk Dnipropetrovskoho derzhavnoho ahrarnoho universy-tetu, 2, 104-107. URL: https://www.academia.edu/33809743/Фізіолого_біохімі чний_статус_голштинської_худоби_за_впливу_гідро гумату_в_поєднанні_3_мікроелементами (in Ukrainian).

Jindo, K., Olivares, F. L., Malcher, D. J. P., SánchezMonedero, M. A., Kempenaar, C., \& Canellas, L. P. (2020). From Lab to Field: Role of Humic Substances Under Open-Field and Greenhouse Conditions as Biostimulant and Biocontrol Agent. Front. Plant Sci., 11, 426. doi: 10.3389/fpls.2020.00426.

Kaukonen, E., Norring, M., \& Valros, A. (2017). Evaluating the effects of bedding materials and elevated platforms on contact dermatitis and plumage cleanliness of commercial broilers and on litter condition in broiler houses. British Poultry Science, 58(5), 480-489. doi: 10.1080/00071668.2017.1340588.

Khokhlov, A. V., Khokhlova, L. I., Kupchyk, L. A., \& Tytarenko, M. V. (2019). Biosorbtsiinyi kompozyt dlia detoksykatsii pestytsydiv u hruntakh. Ekolohichni nauky, 3(26), 59-64. doi: 10.32846/2306-9716-20193-26.11 (in Ukrainian).

Khokhotva, O. P., Kondratenko, O. I., \& Shkel, K. O. (2016). Vykorystannia kompozytsiinoho sorbentu tseolit-huminovi kysloty dlia vyluchennia ioniv midi z 
vodnykh rozchyniv. Visnyk NTU “KhPU”, 18(1190), 180-188. doi: 10.20998/2413-4295.2016.18.27 (in Ukrainian).

Kravchuk, M. M., Dovbysh, L. P., \& Kropyvnytskyi, R. B. (2018). Perspektyvy vykorystannia torfu ta produktiv yoho pererobky v haluzi zemlerobstva. Zbirnyk tez dopovidei naukovo-praktychnoi konferentsii "Naukovi chytannia 2018". Zhytomyr, 58-62. URL: http://znau.edu.ua/images/public_document/2020/Hay кові\%20\%20читання\%202018\%20агрономічний.pd $\mathrm{f}$ (in Ukrainian).

Lotosh, T. D. (1991). Perspektivi primenenija veshhestv guminovoj prirodi. Biologicheskie nauki, 10(334), 29 34 (in Russian).

Medvedeva, N. I., Zajceva, T. B., \& Kuzikova, I. L. (2018). Vlijanie alkilfenolov na chislennost' pochvennyh mik-roorganizmov. Mater. Vserossijskoj nauchnoj konferencii "Himicheskoe i biologicheskoe zagrjaznenie pochvy". Pushhino, 80-83 (in Russian).

Mendes, A. S., Paixão, S. J., Restelatto, R., Reffatti, R., Possenti, J. C., Moura, D. J., de Morello, G. M. Z., de Carvalho, T. M. R. (2011). Effects of initial body weight and litter material on broiler production. Brazilian Journal of Poultry Science, 13(3), 165-170. doi: 10.1590/S1516635X2011000300001.

Neneng, L. (2020). Formulation of Liquid Biofertilizer for Enhance of Soil Nutrients in Peatland. Budapest International Research in Exact Sciences (BirEx) Journal, 2(3), 314-322. doi: 10.33258/birex.v2i3.1068.

Nookongbut, P., Kantachote, D., Khuong, N. Q. et al. (2019). Selection of Acid-Resistant Purple Nonsulfur Bacteria from Peat Swamp Forests to Apply as Biofertilizers and Biocontrol Agents. J Soil Sci Plant Nutr., 19, 488-500. doi: 10.1007/s42729-019-000449.

Ozerchuk, A. M., \& Hnieushev, V. O. (2015). Vyrobnytstvo huminovmisnykh preparativ yak element dyversyfikatsii diial-nosti derzhavnoho kontsernu "Ukrtorf". Materialy Mizhnarodnoi naukovo-praktychnoi konferentsii "Dosiahnennia ta perspektyvy zastosuvannia huminovykh rechovyn $\mathrm{u}$ silskomu hospodarstvi”. Dnipro, 95-96 (in Ukrainian).
Pervachuk, M. V., \& Vradii, O. I. (2015). Symbiotychna fiksatsiia azotu ta rol mikroorhanizmiv $u$ gruntoutvorenni. Silskohospodarske vyrobnytstvo ta lisnytstvo, 1, 102-113 (in Ukrainian).

Pronevych, V. A. (2014). Biolohichna aktyvnist osushenykh torfovykh gruntiv u kormovykh sivozminakh. Silskohospodarska mikrobiolohiia, 19, 42-46. URL: http://nbuv.gov.ua/UJRN/smik_2014_19_7 (in Ukrainian).

Rose, M. T., Patti, A. F., Little, K. R., Brown, A. L., Jackson, W. R., \& Cavagnaro, T. R. (2014). A MetaAnalysis and Review of Plant-Growth Response to Humic Substances: Practical Implications for Agriculture. Advances in Agronomy, 124, 37-89. doi: 10.1016/B978-0-12-800138-7.00002-4.

Situmorang, E. C., Prameswara, A., Sinthya, H. C., Toruan-Mathius, N., \& Liwang, T. (2015). Indigenous Phosphate Solubilizing Bacteria from Peat Soil for an Eco-friendly Biofertilizer in Oil Palm Plantation. KnE Energy, 1(1), 65-72. doi: 10.18502/ken.v1i1.324.

Tyshko, Yu. A., Stepaniuk, A. R., Kopylenko, A. V., \& Voronin, L. H. (2015). Formuvannia ta vlastyvosti huminovykh sub-stantsii. Visnyk Vinnytskoho politekhnichnoho instytutu, 3, 61-66. URL: http://nbuv.gov.ua/UJRN/vvpi_2015_3_11 (in Ukrainian).

Veremeienko, S. I., Strikha, V. A., \& Ozerchuk, A. M. (2017). Perspektyvy vykorystannia torfu dlia vidtvorennia ro-diuchosti gruntiv. Visnyk Zhytomyrskoho natsionalnoho ahroekolohichnoho universytetu, 1(58), 21-29. URL: http://nbuv.gov.ua/ UJRN/Vzhnau_2017_1\%281\%29_5 (in Ukrainian).

Yurchenko, L. I., \& Vereshchun, A. L. (2005). Vplyv oksydatu torfu na orhanizm tvaryn. Problemy zooinzhenerii ta ve-terynarnoi medytsyny: Zbirnyk naukovykh prats KhDZA. Kharkiv, Prapor, 25-34 (in Ukrainian).

Zharikov, G. A., Krajnova, O. A., Marchenko, A. I. i dr. (2018). Razrabotka tehnologi mikrodizirovannogo vnese-nija mikrooorganizmov-destruktorov na zagrjaznennuju pochvu. Mater. Vserossijskoj nauchnoj konferencii "Himicheskoe i biologicheskoe zagrjaznenie pochvy". Pushhino, 178-179 (in Russian). 